\title{
Black scabbardfish, Aphanopus carbo, in the northeast Atlantic: distribution and hypothetical migratory cycle
}

\author{
Inês FARIAS ${ }^{1,2, a}$, Beatriz MORALES-NIN ${ }^{1}$, Pascal LORANCE $^{3}$ and Ivone FIGUEIREDO ${ }^{2}$ \\ 1 Instituto Mediterráneo de Estudios Avanzados (IMEDEA-CSIC/UIB), C/ Miquel Marquès 21, 07190 Esporles, Illes Balears, Spain \\ 2 Instituto Português do Mar e da Atmosfera (IPMA), Av. Brasília, 1449-006 Lisboa, Portugal \\ 3 Institut Français de Recherche pour l'Exploitation de la Mer (Ifremer), rue de l'île d'Yeu, BP 21105, 44311 Nantes Cedex 03, France
}

Received 7 February 2013; Accepted 24 July 2013

\begin{abstract}
The biology, ecology, and dynamics of the deep-sea teleost black scabbardfish in the northeast Atlantic are reviewed. The black scabbardfish is a commercial bathypelagic species found in the NE Atlantic mostly from Iceland to the Canary Islands and Western Sahara, at depths from 800 to $1300 \mathrm{~m}$. The spatial structure of its population is still uncertain, although the existence of one single stock that migrates around the NE Atlantic driven by feeding and reproduction is the most likely hypothesis consistent with available data. This review is based on data from commercial fisheries off the Faroe Islands, Hatton Bank, the west of the British Isles, and Portugal (mainland, Azores, and Madeira) and from Icelandic and Scottish scientific surveys collected between 1988 and 2012. Spawning of black scabbardfish occurs around Madeira and the Canary Archipelagos during the last quarter of the year. According to the migratory hypothesis, eggs, larvae, and possibly juveniles move north to areas from south of Icelandic and Faroe Islands to the west of the British Isles where they remain for some years to feed and grow. Then, they move south to the area off mainland Portugal, where they reach the size of first maturity but do not reproduce, and later move further south to the spawning grounds. Further studies are needed to understand which of the environmental conditions prevailing around Madeira and the Canaries, but not elsewhere, allow this species to mature and subsequently reproduce. This review suggests that a multidisciplinary approach is required to confirm the spatiotemporal migration and habitats used by black scabbardfish populations in the NE Atlantic at different life stages. Otolith contour shape and microchemistry, fatty acids, carbon and nitrogen stable isotopes, as well as steroid hormones are proposed as promising alternative tools for responding to this challenge.
\end{abstract}

Keywords: Deep-water longline fisheries / Migration / Life cycle / Trichiuridae / Aphanopus carbo / North Atlantic Ocean

\section{Introduction}

Aphanopus carbo Lowe, 1839 (Actinopterygii: Trichiuridae) occurs throughout the North Atlantic between $30^{\circ} \mathrm{N}$ and $70^{\circ} \mathrm{N}$, from the strait of Denmark to western Sahara, being most abundant to the south of the Faroe Islands, in the Rockall Trough, to the west of mainland Portugal, and around Madeira and the Canary archipelagos, but also occurring in Iceland, the Mid-Atlantic Ridge and Corner Rise, and the Azores (Nakamura and Parin 1993; Parin 1995; Pajuelo et al. 2008; Machete et al. 2011). The species has also been reported in the western part of the Atlantic, in Greenland, Canada, and the USA (Templeman and Squires 1963; Fitch and Gotshall 1972; Parin and Becker 1972; Peden 1974; Clarke and Wagner 1976; Gorbunova 1977; Howe et al. 1980; Nakamura 1984; Borets 1986; Lauth 1997). Reports of

a Corresponding author: ifarias@ipma.pt
A. carbo occurrence in the eastern Pacific (Clarke and Wagner 1976; Howe et al. 1980; Pequeño 1989; McAllister 1990) and the southern Indian oceans (Piotrovskiy 1981) were deemed questionable by Nakamura and Parin (1993). The absence of confirmed records in those areas, despite the worldwide development of deep-sea fisheries and surveys since the early 1990s, suggests that $A$. carbo is restricted to the North Atlantic.

A. carbo is a bathypelagic species that has been found at depths from $200 \mathrm{~m}$, in the northern section of the NE Atlantic (Nakamura and Parin 1993; Kelly et al. 1998), to $2300 \mathrm{~m}$ around the Canary Islands (Pajuelo et al. 2008), but is more frequent between 800 and $1800 \mathrm{~m}$ in mainland Portugal (Martins et al. 1987), 800 and $1300 \mathrm{~m}$ in Madeira (MoralesNin and Sena-Carvalho 1996), and 400 and $1400 \mathrm{~m}$ off the west of the British Isles (Ehrich 1983; Allain et al. 2003). Its distribution is mainly associated with steep slopes, underwater rises, and canyons to the west of Portugal and along the gentle 
Table 1. Summary of fisheries and surveys from which data on black scabbardfish were available for this review; total length (TL, $\mathrm{cm}$ ), total weight $(\mathrm{g})$, maturity stage.

\begin{tabular}{|c|c|c|c|c|c|c|c|}
\hline Area & Source & Depth (m) & Gear & $\begin{array}{l}\text { Total length } \\
(\mathrm{cm}) \\
\text { range \& mode }\end{array}$ & $\begin{array}{l}\text { Weight } \\
\text { range } \\
(\mathrm{g})\end{array}$ & $\begin{array}{c}\text { Maturity } \\
\text { stage }\end{array}$ & Reference \\
\hline Iceland & $\begin{array}{l}\text { Icelandic autumn } \\
\text { survey }\end{array}$ & $176-1307$ & Bottom trawl & $26-123 \quad 90$ & $572-1960$ & I-II & $\begin{array}{l}\text { K. Jakobsdóttir } \\
\text { (pers. comm.) }\end{array}$ \\
\hline Faroe Islands & Fishery & $N A$ & $\begin{array}{l}\text { Traditional bottom } \\
\text { trawl; doors did not } \\
\text { touch the bottom }\end{array}$ & $65-142 \quad 100$ & $1000-4000$ & $N A$ & ICES 2012 \\
\hline Hatton Bank & Fishery & $1000-1400$ & Bottom trawl & $\begin{array}{ll}71-120 & 87\end{array}$ & $N A$ & Immature & ICES 2012 \\
\hline $\begin{array}{l}\text { West British } \\
\text { Isles }\end{array}$ & $\begin{array}{l}\text { Fishery; Scottish } \\
\text { deep water survey }\end{array}$ & $500-1800$ & Bottom trawl & $62-130 \quad 90$ & $232-2740$ & I-II & $\begin{array}{l}\text { This study; Ribeiro } \\
\text { Santos et al. 2013a }\end{array}$ \\
\hline Mainland Portugal & Fishery & $800-1450$ & Bottom longline & $53-136 \quad 105$ & $137-3650$ & I-III & This study \\
\hline Azores & $\begin{array}{l}\text { Experi- } \\
\text { mental fishery }\end{array}$ & $650-1900$ & $\begin{array}{l}\text { Drifting bottom } \\
\text { longline }\end{array}$ & $60-156 \quad 120$ & $N A$ & $N A$ & Machete et al. 2011 \\
\hline Madeira & Fishery & $\sim 1000$ & $\begin{array}{l}\text { Drifting horizontal } \\
\text { longline }\end{array}$ & 51-151 117 & $131-4020$ & All & $\begin{array}{l}\text { This study; Bordalo- } \\
\text { Machado et al. } 2009\end{array}$ \\
\hline
\end{tabular}

NA: not available.

sedimentary slope to the west of the British Isles (Martins et al. 1987; ICES 2012). Information regarding the black scabbardfish available from fisheries and surveys in the NE Atlantic is summarised in Table 1.

Although no eggs or larvae of black scabbardfish have been found, juveniles are reported to be mesopelagic (Parin 1986). Maul (1950) found two small specimens (10 and $15 \mathrm{~cm}$ total length) in the stomach of a long snouted lancetfish (Alepisaurus ferox Lowe, 1833). More recently, a specimen of approximately $10 \mathrm{~cm}$, identified by DNA barcoding, was caught at the Senghor Seamount, off the northeast of Cape Verde (Hanel et al. 2010). There are also records of fish as small as $26 \mathrm{~cm}$ from Icelandic surveys (Table 1).

In terms of morphology, this species has a narrow elongated body with a pointed head and long dorsal fin, adapted for fast swimming; a large terminal mouth with large fang-like teeth, modified for efficient predation; large eyes (diameter is about a fifth to a sixth of head length) that facilitate sight in low light; and a coppery-black coloration with an iridescent tint to facilitate camouflage (Parin 1986; Nakamura and Parin 1993; Merrett and Haedrich 1997). Life history traits such as diet, growth, reproduction, and energy consumption are directly dependent on physical conditions of the deep sea such as high pressure and low temperature, which hinder the metabolic rate processes of fishes, as well as on predation stress and low food availability (Graham et al. 1985; Merrett and Haedrich 1997).

Recently, it was found that $A$. carbo coexists spatially with Aphanopus intermedius Parin, 1983 in the Azores, Madeira, the Canaries, and off the coasts of Morocco and the western Sahara (Nakamura and Parin 1993; Stefanni and Knutsen 2007; Stefanni et al. 2009; Biscoito et al. 2011). However, it has been genetically confirmed that $A$. carbo is the only species that reaches the northernmost latitudes of the NE Atlantic (Stefanni and Knutsen 2007; Biscoito et al. 2011; Ribeiro Santos et al. 2013a). The two species are morphologically very similar, yet both genetics (Stefanni and Knutsen 2007; Knutsen et al. 2009;
Stefanni et al. 2009) and meristic characteristics (Tuset et al. 2010; Biscoito et al. 2011) have proven suitable for reliable identification. Throughout this manuscript the common names accepted by FAO are used: black scabbardfish for A. carbo and intermediate scabbardfish for A. intermedius.

How the black scabbardfish completes its life cycle is still in question. The most widespread hypothesis is that one single stock undertakes a large-scale clockwise migration around the NE Atlantic. Under this hypothesis, spawning is restricted to areas off Madeira, the Canary Islands, and possibly further south. Thereafter, juveniles recruit to the fisheries south of Iceland, around the Faroe Islands, and to the west of the British Isles, where they stay to feed and grow for a few years. From there, they first move south towards mainland Portugal and then further south to the spawning areas (Fig. 1).

Some specific habitat properties that allow the metabolic processes inherent to reproduction, survival of eggs and larvae or both might exist exclusively around Madeira and the Canaries and hence merit further investigation.

\section{State-of-the-art}

\subsection{Fisheries}

There are three main deep-sea fisheries targeting the black scabbardfish in the NE Atlantic: (i) to the west of the British Isles, fish are mainly exploited by the French deep-sea trawl fishery (Nakamura and Parin 1993; ICES 2012); (ii) an artisanal fleet operates with bottom longlines in ICES (International Council for the Exploration of the Seas) Subarea IXa, off mainland Portugal (Bordalo-Machado et al. 2009; ICES 2012); and (iii) a third important commercial fishery is operated by artisanal horizontal drifting longliners off the Madeira Archipelago, within the CECAF (Fishery Committee for the Eastern Central Atlantic) area (Bordalo-Machado et al. 2009). The fishery in Madeira dates back to the seventeenth century (Merrett and Haedrich 1997), whereas it started in mainland 


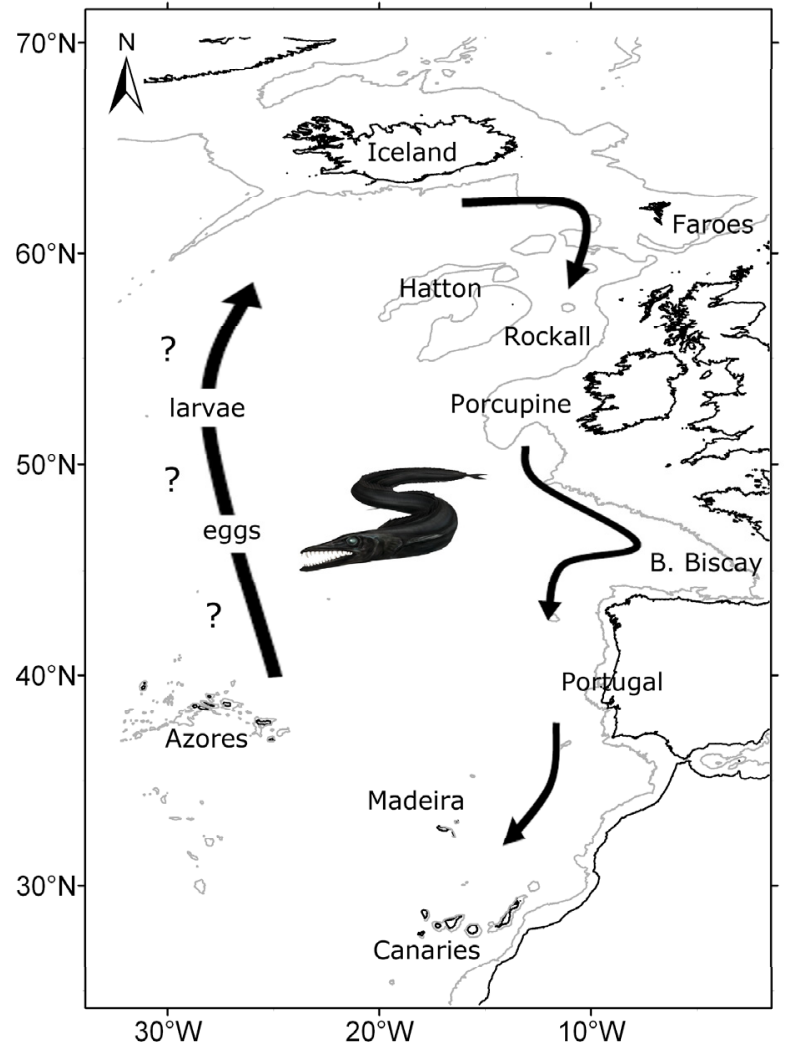

Fig. 1. Map of the northeast Atlantic Ocean representing the hypothetical migratory cycle of the black scabbardfish. The $1000 \mathrm{~m}$ depth contour is shown (drawing of black scabbardfish adapted from MARPROF, www.marprof.org).

Portugal in the early 1980s (Martins et al. 1987) and in northern Europe in the early 1990s (Merrett and Haedrich 1997). In ICES Subarea X, another directed fishery has recently started in Azorean waters (Portugal) (Machete et al. 2011). In Madeira and the Azores, A. intermedius might be landed mixed with A. carbo (Stefanni and Knutsen 2007). Additionally, a few smaller and interrupted fisheries occur in Faroese and Icelandic waters where the species is exploited by both longliners and trawlers (ICES 2012) and in the Canary Islands, where it is exploited by drifting mid-water longliners (Pajuelo et al. 2008).

The trend in black scabbardfish landings in ICES northern (Subareas Vb, VI, VII and XII) and southern (Subareas IXa and VIII) components in the last two decades is shown in Figure 2. Estimated landings in 2011 were $2357 \mathrm{t}$ for ICES Subareas VI and VII (W British Isles), $2781 \mathrm{t}$ for mainland Portugal (ICES 2012) and $1941 \mathrm{t}$ for Madeira (Anon. 2012). Regarding the smaller fisheries, landings increased from $139 \mathrm{t}$ in 2011 to $458 \mathrm{t}$ in 2012 in the Azores (M. Ruivo, pers. comm.); reached $109 \mathrm{t}$ in Iceland in 2010 (no data was provided for 2011); and were $111 \mathrm{t}$ caught by Spanish vessels in SE Greenland, ICES Division XIV in 2010 (ICES 2012).

\subsection{Age, growth, and length structure}

Over time, studies on age and growth of the black scabbardfish have led to different conclusions (Table 2): initially,
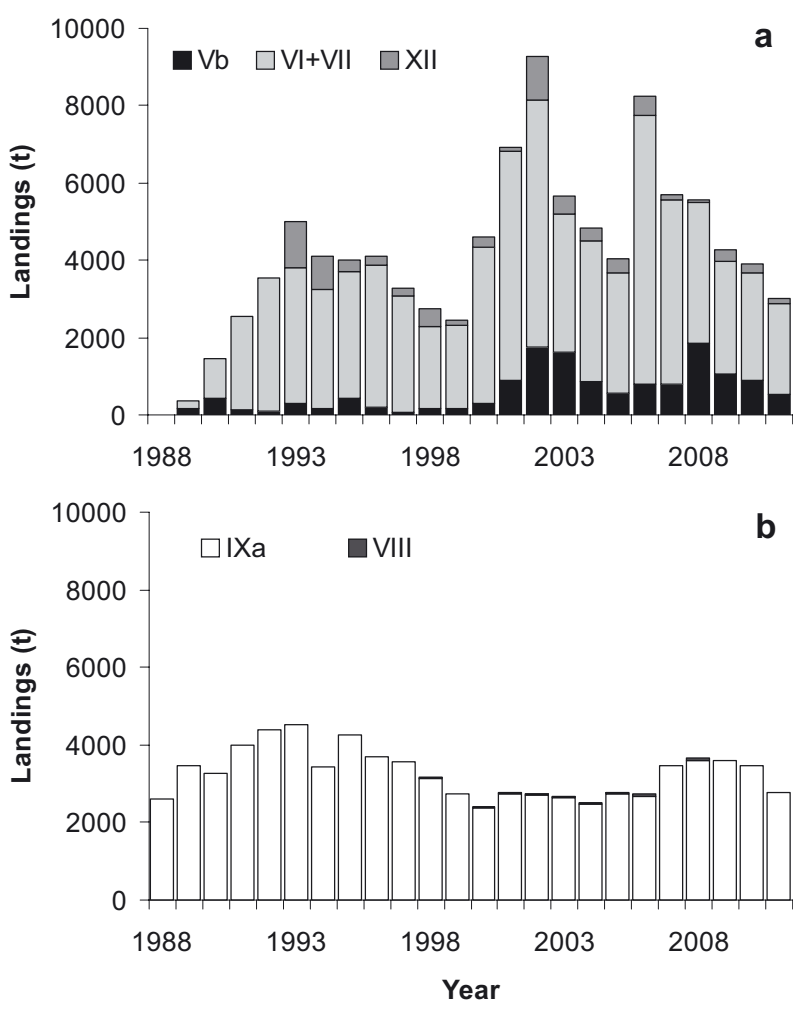

Fig. 2. Annual black scabbardfish landings from 1988 to 2011 for ICES, (a) northern component: ICES Division Vb (around Faroe Islands), VI+VII (west of the British Isles), and XII (north of the Azores); and (b) southern component: ICES Subarea VIII (Bay of Biscay), and Division IXa (west of mainland Portugal). Landings data are from ICES (2012). 2011 data are provisional.

the maximum age was estimated to be 8 years for fish from Madeira (Morales-Nin and Sena-Carvalho 1996) and 32 years for the Rockall Trough (Kelly et al. 1998). Later, it was determined to be 12 years for Madeira and the Canaries (MoralesNin et al. 2002; Pajuelo et al. 2008). More recently, the maximum age was estimated to be 12 years in mainland Portugal (Vieira et al. 2009) and 14 years in Madeira (Vieira et al. 2009; Delgado et al. 2013). Since the length range used in all studies was similar, the differences might be associated with the age assignment criteria, otolith preparation techniques, quality of the equipment used or experience of the readers.

The maximum age estimated by Morales-Nin and SenaCarvalho (1996) corresponded to a male of $130 \mathrm{~cm}$ and a female of $150 \mathrm{~cm}$ total length. These ages were probably underestimated because, when using whole otoliths in larger specimens from this species, the growth increments closer to the border are very difficult to identify (Vieira et al. 2009). On the contrary, the maximum age assigned by Kelly et al. (1998) using thin otolith sections was most likely overestimated since, with this preparation technique, the number of visible rings is very high and the authors reported problems in their interpretation. Regarding age estimations in Madeira and the Canary Islands in studies prior to 2008, when caught specimens started being routinely separated by species, the possible mixing of black and intermediate scabbardfish specimens could also explain the differences found between regions and should be 
Table 2. Von Bertalanffy growth parameter estimates from different studies carried out in the NE Atlantic, including otolith age reading method and clearing solution. F: female, M: male, SD: standard deviation.

\begin{tabular}{|c|c|c|c|c|c|c|c|c|c|c|}
\hline Area & Method & Clearing & Sex & $N$ & $\begin{array}{c}\text { Total } \\
\text { length } \\
\text { range }(\mathrm{cm}) \\
\end{array}$ & $\begin{array}{l}\text { Age } \\
\text { range } \\
\text { (year) } \\
\end{array}$ & $\begin{array}{l}L_{\mathrm{inf}} \pm \mathrm{SD} \\
\quad(\mathrm{cm})\end{array}$ & $\begin{array}{c}\boldsymbol{k} \\
\left(\text { year }^{-1}\right)\end{array}$ & $\begin{array}{c}t_{0} \\
\text { (year) }\end{array}$ & Source \\
\hline $\begin{array}{l}\text { W. British } \\
\text { Isles }\end{array}$ & $\begin{array}{l}\text { Thin sections } \\
\text { in epoxy resin }\end{array}$ & Alcohol & both & 230 & $75-120$ & $4-32$ & $N A$ & 0.1 & $N A$ & $\begin{array}{l}\text { Kelly } \\
\text { et al. } 1998\end{array}$ \\
\hline \multirow{2}{*}{$\begin{array}{l}\text { Mainland } \\
\text { Portugal }\end{array}$} & \multirow{2}{*}{$\begin{array}{l}\text { Thin sections } \\
\text { in epoxy resin }\end{array}$} & \multirow{2}{*}{$\begin{array}{l}\text { 1:1 glycerin- } \\
\text { alcohol }\end{array}$} & $\mathrm{F}$ & 248 & \multirow{2}{*}{ 64-131 } & $5-13$ & $135 \pm 4$ & 0.2 & -2.0 & \multirow{2}{*}{$\begin{array}{l}\text { Vieira } \\
\text { et al. } 2009\end{array}$} \\
\hline & & & M & 206 & & $4-10$ & $124 \pm 3$ & 0.2 & -1.7 & \\
\hline \multirow{7}{*}{ Madeira } & \multirow{3}{*}{ Surface } & \multirow{3}{*}{ Glycerol } & $\mathrm{F}$ & 334 & $58-151$ & \multirow{3}{*}{$0-8$} & 142 & 0.3 & -2.1 & \multirow{3}{*}{$\begin{array}{c}\text { Morales-Nin } \\
\text { and Sena- } \\
\text { Carvalho } 1996\end{array}$} \\
\hline & & & $M$ & 357 & $58-132$ & & 155 & 0.2 & -3.3 & \\
\hline & & & both & 649 & $58-151$ & & 139 & 0.3 & -2.3 & \\
\hline & \multirow{2}{*}{$\begin{array}{l}\text { Thin sections } \\
\text { in epoxy resin }\end{array}$} & \multirow{2}{*}{$\begin{array}{c}\text { 1:1 glycerin- } \\
\text { alcohol }\end{array}$} & $\mathrm{F}$ & 200 & \multirow{2}{*}{$125-148$} & $8-15$ & $159 \pm 4$ & 0.1 & -2.3 & \multirow{2}{*}{$\begin{array}{c}\text { Vieira } \\
\text { et al. } 2009\end{array}$} \\
\hline & & & M & 163 & & $8-14$ & $146 \pm 1$ & 0.1 & -1.4 & \\
\hline & \multirow{2}{*}{ Surface } & \multirow{2}{*}{$\begin{array}{c}\text { 1:1 glycerin- } \\
\text { alcohol }\end{array}$} & $\mathrm{F}$ & \multirow{2}{*}{554} & \multirow{2}{*}{$100-140$} & \multirow{2}{*}{$6-14$} & $136 \pm 5$ & 0.2 & -4.2 & \multirow{2}{*}{$\begin{array}{c}\text { Delgado } \\
\text { et al. } 2013\end{array}$} \\
\hline & & & $\mathrm{M}$ & & & & $132 \pm 5$ & 0.2 & -3.1 & \\
\hline \multirow{3}{*}{$\begin{array}{l}\text { Canary } \\
\text { Islands }\end{array}$} & \multirow{3}{*}{$\begin{array}{l}\text { Surface, } \\
\text { burned }\end{array}$} & \multirow{3}{*}{$\begin{array}{c}50 \% \\
\text { glycerol }\end{array}$} & $\mathrm{F}$ & 196 & $100-148$ & $2-12$ & $149 \pm 2$ & 0.2 & -4.7 & \multirow{3}{*}{$\begin{array}{l}\text { Pajuelo } \\
\text { et al. } 2008\end{array}$} \\
\hline & & & M & 102 & 104-134 & $2-8$ & $141 \pm 4$ & 0.3 & -3.5 & \\
\hline & & & both & 298 & $100-148$ & $2-12$ & $148 \pm 2$ & 0.2 & -4.6 & \\
\hline
\end{tabular}

NA: not available.

taken into consideration. The maximum ages assigned by Delgado et al. (2013) using whole otoliths were 14 years for black scabbardfish and 15 years for intermediate scabbardfish. Overall, the age estimation of the black scabbardfish is difficult and has not yet been validated. Both the seasonality of the deposition of material at the otolith margin and of daily growth increments would deserve additional studies with standardised methods using material from all areas and seasons.

The growth parameters estimated based on the von Bertalanffy growth equation showed a relatively rapid growth rate for the black scabbardfish (Table 2). Figure 3 represents the growth curves according to sex for all available studies, restricted to the length range of each fish sample. Growth estimates from Vieira et al. (2009) and Delgado et al. (2013) seem to be in agreement, without any meaningful area effect. Ageat-length from Kelly et al. (1998) was consistently higher than in all the other studies. This implies a low $\mathrm{k}$ for fish from the west of the British Isles which is not in agreement with the predominance of young immature specimens in this area.

Rapid growth of deep-sea juvenile fishes has been shown to be an advantageous strategy in feeding success and predation avoidance (Crabtree and Sulak 1986). Nonetheless, in the results of Vieira et al. (2009) the absence of small individuals caught off Madeira may have interfered with the accuracy of the growth parameter estimates. In contrast, slow growth rate is observed for adults, as a result of a transfer of energy investment from growth to reproduction (Lika and Nisbet 2000). This strategy contrasts with that of species whose growth continues after maturation, such as most shelf demersal and pelagic commercial fish.

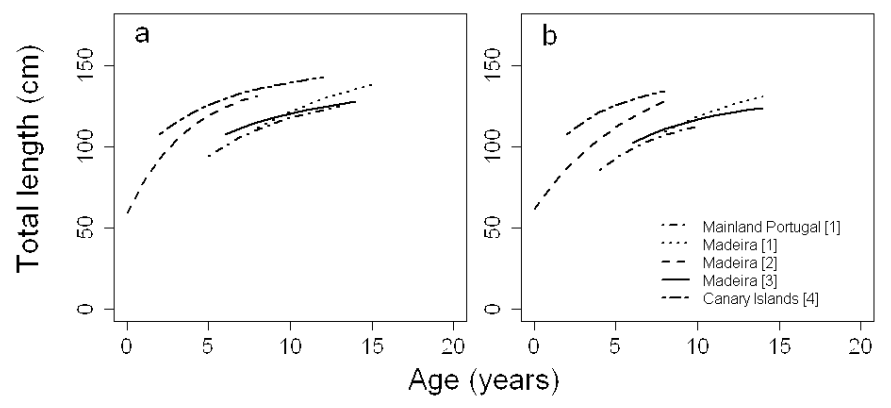

Fig. 3. Growth curves for black scabbardfish from different studies, areas and methods. (a) females; (b) males. Growth parameters are from [1] Vieira et al. (2009); [2] Morales-Nin and Sena-Carvalho (1996); [3] Delgado et al. (2013); [4] Pajuelo et al. (2013).

Size ranges reported for different areas in the NE Atlantic are presented in Table 1 . The smallest specimens were reported in Iceland, where this species can be caught in relatively shallow waters, whereas the largest fish were caught off the Azores, where this species reaches deeper waters.

Length frequency distributions for different ICES and CECAF management units in 2011 are presented in Figure 4. The French fleet operates mainly in ICES Division VIa but also in Vb and VII; the Spanish fleet in Divisions VIb and XIIb; the Portuguese longline fishery in Division IXa; the Azores fleet in Subarea X (ICES 2012); and the Madeira fleet in CECAF division 34.1.2 (Delgado et al. 2013). Moreover, data from Subarea X were collected during Faroese surveys 


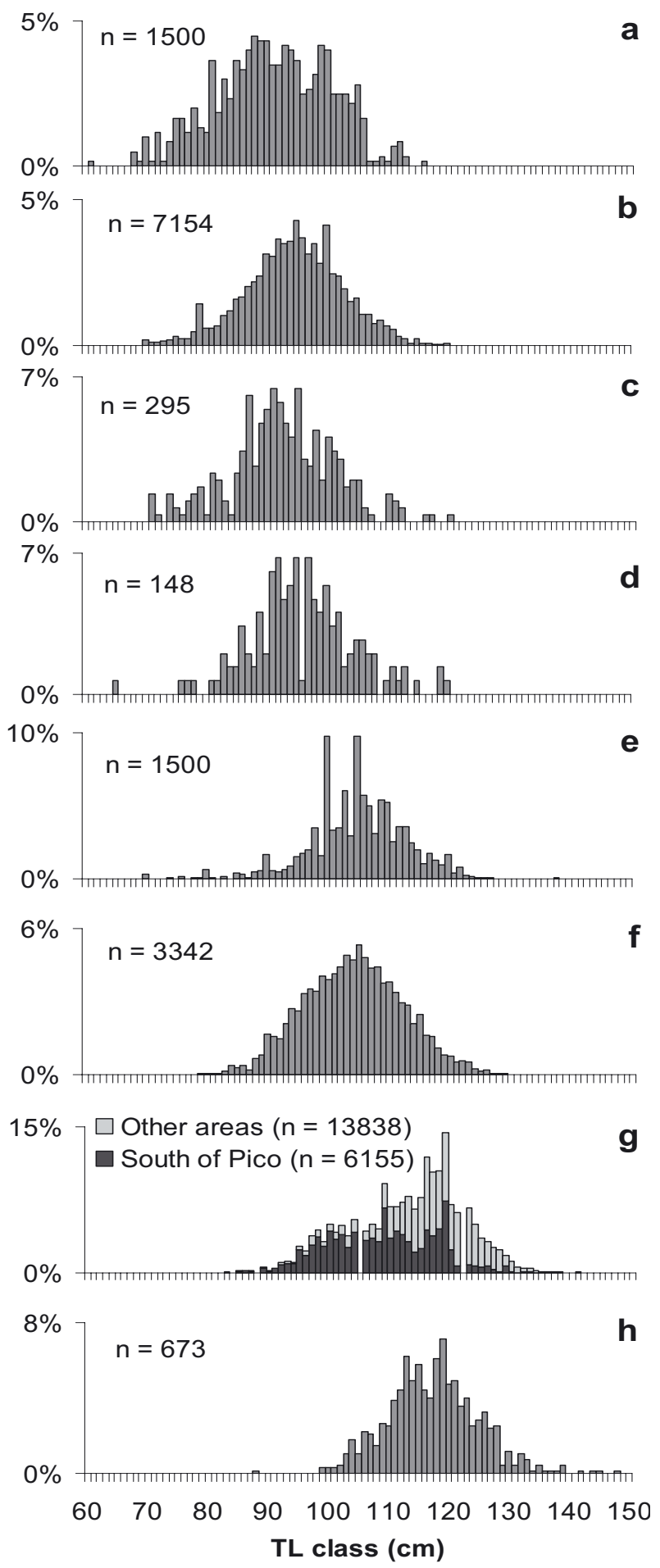

Fig. 4. Length frequency distribution of black scabbardfish in 2011 from north to south: (a) Icelandic surveys (ICES Division Va); (b) onboard observations of French trawlers (mostly in ICES Division VIa); (c) on-board observations of Spanish trawlers off the west of the British Isles (VIb); (d) on-board observations of Spanish trawlers (Subarea XII); (e) self-sampling Faroese exploratory surveys (Subarea X); (f) Portuguese longline fishery off mainland Portugal (IXa); (g) experimental fishery in the Azores (data are from 2005); (h) sampling of commercial landings in Madeira. Length frequency data are from [a-f] ICES (2012); [g] Machete et al. (2011); [h] Delgado et al. (2013).
(ICES 2012). In general, the size distributions move towards higher values from north to south of the NE Atlantic. In the Azores, the bimodal length distribution found to the south of Pico (Fig. $4 \mathrm{~g}$ ) is probably a consequence of mixing between A. carbo and A. intermedius, since the latter species has been described in this area (Stefanni and Knutsen 2007).

\subsection{Diet}

The black scabbardfish is a top predator, which feeds on a large food spectrum (Zilanov and Shepel 1975; Nakamura and Parin 1993; Ribeiro Santos et al. 2013b). Diet studies based on gut content analyses are difficult in this species because, most of the time, these are either already fully digested or have been regurgitated as a result of hydrostatic decompression, as happens in deep-sea fishes that have a swim bladder (Stowasser et al. 2009). This difficulty is worsened when sampling fish are caught by the commercial longlines off Madeira and mainland Portugal because the soaking time can be up to $40 \mathrm{~h}$ (BordaloMachado et al. 2009), enabling the full digestion of the stomach contents. As a consequence, the vacuity index calculated for fish from Madeira was 93 to $98 \%$ (Freitas 1998; Ribeiro Santos et al. 2013b), whereas it varied from 66 to $94 \%$ for specimens caught by trawls to the west of the British Isles (Mauchline and Gordon 1984; Ribeiro Santos et al. 2013b) (Table 3).

Table 3 summarizes the published information on the diet of the black scabbardfish in the NE Atlantic. To the west of the British Isles, several studies have focused on the diet of this species. Du Buit (1978) identified two fish taxa, Argentina sp. (Osmeriformes) and Gadidae, in eight non-empty stomachs. Mauchline and Gordon (1984) and Ribeiro Santos et al. (2013b) found mostly fish, namely blue whiting (Micromesistius poutassou), and a small amount of cephalopods. The differences between these studies may be related to the seasonal changes observed by Ribeiro Santos et al. (2013b) who associated the decrease in blue whiting and consequent increase in cephalopods and crustaceans in the diet of the black scabbardfish with the migration of blue whiting to the Norwegian Sea. In fact, when Howell et al. (2009) combined the diet composition of fish caught by scientific surveys off the Rockall Trough with earlier data from Mauchline and Gordon (1984), the resulting diet was approximately $50 \%$ cephalopods and $44 \%$ blue whiting.

In fish caught off Madeira, the main prey were the cephalopods Chiroteuthis spp., Mastigoteuthis sp., Histioteuthis sp., and Taonius sp., and the fish Chauliodus sp., as well as several Myctophidae (Freitas 1998). The differences between the diets of black scabbardfish caught off the British Isles and off the Madeira archipelago may be related to food availability given that, in the latter area, no large stocks of small pelagic and mesopelagic fish, such as blue whiting, can be found.

\subsection{Reproduction}

The black scabbardfish is an iteroparous species, since it can spawn multiple times throughout its life, and is also a total spawner, as it spawns in one single event (Pajuelo et al. 2008; Ribeiro Santos et al. 2013a). Moreover, it has determinate 
Table 3. Summary of the diet composition of black scabbardfish caught in the NE Atlantic.

\begin{tabular}{|c|c|c|c|c|c|c|c|}
\hline Area & Depth (m) & $\begin{array}{c}\text { Total } \\
\text { length } \\
\text { range }(\mathrm{cm})\end{array}$ & $\begin{array}{c}\text { No. } \\
\text { stomachs } \\
\text { sampled } \\
\end{array}$ & $\begin{array}{c}\text { No. } \\
\text { stomachs } \\
\text { with food }\end{array}$ & $\begin{array}{c}\text { Vacuity } \\
\text { index } \\
(\%)\end{array}$ & Main prey & Source \\
\hline \multirow{4}{*}{$\begin{array}{l}\text { West British } \\
\text { Isles }\end{array}$} & $750-1100$ & 80 (a) & $N A$ & 8 & $N A$ & $\begin{array}{l}\text { Fish (Argentina sp. } \\
\text { and Gadidae) }\end{array}$ & Du Buit 1978 \\
\hline & $500-1250$ & $77-108$ & 142 & 52 & 66.2 & $\begin{array}{l}\text { Fish (Micromesistius } \\
\text { poutassou and } \\
\text { Scombridae) and } \\
\text { cephalopods }\end{array}$ & $\begin{array}{l}\text { Mauchline and } \\
\text { Gordon } 1984\end{array}$ \\
\hline & $N A$ & $N A$ & $N A$ & $N A$ & $N A$ & $\begin{array}{l}\text { Cephalopods, fish } \\
\text { (Micromesistius } \\
\text { poutassou), prawns } \\
\text { and shrimps }\end{array}$ & $\begin{array}{l}\text { Howell et al. } 2009 \\
\text { (including data } \\
\text { from Mauchline } \\
\text { and Gordon 1984) }\end{array}$ \\
\hline & $500-1800$ & $97 \pm 7(b)$ & 1581 & 133 & 91.6 & $\begin{array}{l}\text { Fish (Micromesistius } \\
\text { poutassou and } \\
\text { mesopelagic species) } \\
\text { and cephalopods }\end{array}$ & $\begin{array}{l}\text { Ribeiro Santos } \\
\text { et al. } 2013 b\end{array}$ \\
\hline Madeira & $600-1300$ & $\sim 110-150$ & 3688 & 378 & 93.3 & $\begin{array}{l}\text { Cephalopods } \\
\text { (Chiroteuthis spp., } \\
\text { Mastigoteuthis sp., } \\
\text { Histioteuthis sp., and } \\
\text { Taonius sp.) and } \\
\text { fish Chauliodus sp. } \\
\text { and Myctophidae) }\end{array}$ & $\begin{array}{l}\text { Morales-Nin } \\
\text { and Sena-Carvalho } \\
\text { 1996; Freitas } 1998\end{array}$ \\
\hline
\end{tabular}

(a) Mean. (b) Mean \pm standard deviation.

fecundity, which means that the potential annual fecundity corresponds to the number of vitellogenic oocytes minus the number of oocytes reabsorbed on account of atresia (Neves et al. 2009; Ribeiro Santos et al. 2013a). Mature and spawning adults have only been observed in the last quarter of the year in Madeira (Figueiredo et al. 2003; Neves et al. 2009; Ribeiro Santos et al. 2013a), the Canaries (Pajuelo et al. 2008), and the northwest coast of Africa (Perera 2008). Estimated female length at first maturity $\left(\mathrm{L}_{50}\right)$ was $103 \mathrm{~cm}$ around Madeira (Figueiredo et al. 2003) and $114 \mathrm{~cm}$ around the Canary Islands (Pajuelo et al. 2008). Once again, the possible mixture of black and intermediate scabbardfish specimens in the samples may have biased these results. In a more recent work, female $\mathrm{L}_{50}$ was estimated to be $111 \mathrm{~cm}$ for Madeira and $116 \mathrm{~cm}$ when also including specimens from the west of the British Isles (Ribeiro Santos et al. 2013a). These values are probably overestimated because the estimation did not include specimens from Madeira smaller than $92 \mathrm{~cm}$ in total length. Despite the available information questions remain on the reproductive dynamics of this species.

First, why does the black scabbardfish not mature and spawn elsewhere than Madeira and the Canaries? In mainland Portugal, vitellogenesis begins at the same time as in those areas and a high proportion of caught individuals (ca. 25\%) is larger than $\mathrm{L}_{50}$ (Figueiredo et al. 2003; Neves et al. 2009). Additionally, although reported in the past at Porcupine Bank, to the west of the British Isles (Ehrich 1983) and in Icelandic waters (Magnússon and Magnússon 1995), reproduction has not been observed in these locations since. In fact, even though fish attain relatively high total length, only maturity stages I and II have been observed in either of these areas (Table 1). Because gonad macroscopic features are difficult to interpret, which could have led to incorrect assignments of maturity stage in the past, a standardized maturity scale was proposed for the black scabbardfish (Gordo et al. 2000).

In terms of physiological condition indicators, the gonadosomatic index (GSI) is higher around Madeira than off mainland Portugal (Neves et al. 2009) and to the west of the British Isles (Ribeiro Santos et al. 2013a) for the same body length. Furthermore, atresia occurs in stage II ovaries from fish caught off the previous areas before and during the spawning period (Neves et al. 2009; Ribeiro Santos et al. 2013a). The most likely hypothesis is that intrinsic (e.g., energy budget, chemical predisposition) and extrinsic (e.g., water temperature) factors that condition the maturity process are lacking in the previous areas mentioned above. Fish in a poor nutritional state would cease the maturation process and remain in the same location, whereas fish in a better state would migrate to areas that provide the environmental conditions to optimize spawning and the survival of eggs and larvae (Neves et al. 2009; Ribeiro Santos et al. 2013a). The differences found in GSI are in accordance with the proposed hypothesis for population dynamics, even though no conclusions regarding migratory movements can be drawn from it.

Steroid hormones are responsible for triggering reproductive processes such as gametogenesis, so their levels are expected to change during the reproductive cycle and to be different between fish in distinct maturity stages (Modesto and Canário 2003). In an on-going study, variations in the level of steroid hormones in the plasma of black scabbardfish caught 
off Madeira and mainland Portugal are being analysed (Farias et al., unpublished). Further work is needed to assess whether the study of steroid hormones in black scabbardfish in different areas and seasons would help us to understand the relationship between the migratory and reproductive cycles.

A second question is whether females are able to reproduce in consecutive years. Females spawn all oocytes contained in their ovaries in a single event at each reproductive cycle. Therefore, all females larger than the length at first maturity are expected to mature and spawn simultaneously. Assuming that the age at maturity is approximately 6.5 years (after Figueiredo et al. 2003 and Vieira et al. 2009) and that the oldest specimens found were 14 years old (Vieira et al. 2009; Delgado et al. 2013), females are expected to be able to spawn for a period of 8 years. However, the presence of nonreproductive adults mixed with spawning adults in Madeira during the spawning period suggests that skipped spawning may occur in this species (Neves et al. 2009; Ribeiro Santos et al. 2013a). Skip spawning is an efficient strategy for saving energy that can then be allocated to growth and large scale migration (Ribeiro Santos et al. 2013a), as well as to subsequent reproduction.

\subsection{Migration}

Techniques to study the migration of coastal species, namely mark-recapture, tagging, telemetry, hydroacoustics and diet composition, are difficult to apply to deep-sea species owing to sampling constraints that result from depth and pressure. An innovative combination of tools that may provide complementary information for clarifying the migration pattern, stock structure and spatiotemporal dynamics of this species in the NE Atlantic could include otolith microstructure, otolith shape, fatty acids, and stable isotopes. Multidisciplinary studies carried out so far to uncover these aspects are quickly reviewed below.

In a previous study, black scabbardfish from the three Portuguese directed fisheries (mainland, Madeira, and the Azores) was characterized in terms of reproductive strategy (Neves et al. 2009), growth (Vieira et al. 2009), otolith shape (Farias et al. 2009), parasites (Santos et al. 2009), and contamination (Costa et al. 2009), with the goals of identifying its stock structure and assessing its biochemical composition. The differences found between areas support the migratory hypothesis but do not provide proof because they are mainly dependent on the ontogenetic structure of each sampling location, besides reflecting an unbalanced sampling scheme, given that the sample size collected off the Azores was much smaller than for the other areas.

Otolith contour shape analysis was used to discriminate specimens from mainland Portugal, the Azores, and Madeira (Farias et al. 2009). Differences were found in otolith contour shape between geographical regions, which is in agreement with the hypothesis of fish remaining a few years at each location. In another study, otolith shape supported the existence of a single population of black scabbardfish off Madeira and the Canaries, but the number of specimens was too small to be conclusive (Tuset et al. 2013). This result is very interesting in terms of the migration hypothesis and its relation with the reproductive cycle because it is evidence that fish from Madeira and the Canaries constitute the same population.

\subsubsection{Fatty acids}

In fishes, fatty acids (FA) can be used as indicative biomarkers for different trophic levels (Kirsch et al. 2000). Preliminary results of analyses performed on black scabbardfish muscle indicate that immature specimens caught off Iceland and the west of the British Isles accumulate mainly oleic acid, which is a precursor of all omega-3 and omega-6 polyunsaturated fatty acids (PUFA) (Dalsgaard et al. 2003). Additionally, in fishes caught off Madeira, which were mostly mature, and mainland Portugal, which are mostly in the developing and pre-spawning stages, a prevalence of PUFA, namely arachidonic acid and docosapentaenoic acid, has been observed (Farias et al., unpublished). PUFA are precursors of prostaglandins, which have an important role in reproduction, stimulating ovulation and spawning and eliciting female sexual behaviour (Stacey and Goetz 1982), and their prevalence in specimens from Madeira and mainland Portugal might be related to the predominance of pre-spawning and spawning maturity stages.

Similar results were obtained by Nogueira et al. (2013), who analysed FA in the muscle and liver of black scabbardfish caught off Madeira. The main differences between these two studies are in two monounsaturated fatty acids (MUFA), which were not detected in muscle samples in Nogueira et al. (2013), but were found in muscle samples from all the geographical areas analysed in the aforementioned study (Farias et al., unpublished). These divergences might result from differences in apparatus sensitivity, as well as from the deterioration of the tissues, since the samples analysed by Nogueira et al. (2013) were left in ice for 1-2 days between capture and laboratory analyses.

\subsubsection{Stable isotopes}

Ribeiro Santos et al. (2013b) analysed the diet of black scabbardfish caught off Madeira and to the west of the British Isles in terms of $\delta^{15} \mathrm{~N}$ and $\delta^{13} \mathrm{C}$ and concluded that this species forms a link between the pelagic and the benthopelagic food webs, reflecting preferred feeding on pelagic fish and cephalopods. Seasonal changes in $\delta^{15} \mathrm{~N}$ were observed in fish caught off the west of the British Isles, supporting a shift to prey of a lower trophic level during the season when blue whiting migrates northward. The observed depletion in $\delta^{13} \mathrm{C}$ in November in fish from Madeira could result from adults moving to shallower waters closer to the shore to spawn, as reported by local fishermen, which would imply a change between very different food sources (DeNiro and Epstein 1978). $\delta^{13} \mathrm{C}$ of black scabbardfish caught in the Bay of Biscay (5 individuals, Chouvelon et al. 2012) was intermediate between values from the west of the British Isles and Madeira from Ribeiro Santos et al. (2013b), whereas $\delta^{15} \mathrm{~N}$ was lower.

Preliminary results obtained for samples caught off Madeira and the west of the British Isles, as well as mainland 
Portugal and Iceland, are intermediate between those of previous work (Farias et al., unpublished). Mean $\delta^{15} \mathrm{~N}$ is lower than the values presented by Ribeiro Santos et al. (2013b) but higher than the estimates obtained for the Bay of Biscay. The mean $\delta^{13} \mathrm{C}$ for Iceland and the west of the British Isles is higher than the estimate of Ribeiro Santos et al. (2013b) for the latter area, whereas the values from fish caught in the two southernmost areas are higher than the value for Madeira. The differences between studies suggest annual or seasonal variations associated with the sampling periods, which need to be further analysed. It is worth noting that the similar $\delta^{13} \mathrm{C}$ observed in fish caught off Iceland and the west of the British Isles is supported by the geographical proximity between these sampling sites, whereas different mean $\delta^{15} \mathrm{~N}$ reflects dissimilarities in the diet of black scabbardfish between these regions (Farias et al., unpublished).

\section{Discussion}

The assessment of exploited populations and the subsequent proposal of management measures are focused on stocks. There are several definitions for stock but the most commonly agreed upon is that it is a group of fishes with similar life history characteristics large enough to be selfreproducing (Hilborn and Walters 1992). Since the stock structure is still unknown for most exploited species, stock units are adopted for management purposes. These units are reasonably heterogeneous for a number of biological, spatial, and temporal dimensions (Hilborn and Walters 1992). In the case of the black scabbardfish, ICES considers three management units (ICES 2012): "Northern" (Divisions Vb and XIIb and Subareas VI and VII); "Southern" (Subareas VIII and IX); and "Other areas" (Divisions IIIa and Va Subareas I, II, IV, X, and XIV).

Quinta et al. (2004) found genetic evidence of the black scabbardfish population being genetically structured into two groups: those from the eastern Atlantic (mainland Portugal and the Hatton Bank) and those from around the Madeira archipelago. However, it is now clear that these results were most likely confounded by the occurrence of A. intermedius around Madeira (Stefanni and Knutsen 2007; Knutsen et al. 2009; Stefanni et al. 2009).

The current understanding of the population dynamics of black scabbardfish in the NE Atlantic implies that spawning occurs around Madeira, the Canary Islands, and possibly a few other southern areas, like the NW coast of Africa (Figueiredo et al. 2003; Pajuelo et al. 2008; Perera 2008; Neves et al. 2009). Juveniles occur mainly in the northernmost areas, namely Iceland, the Faroe Islands, and the west of the British Isles, where small fish of 2-3 years old are caught by fisheries and surveys. The northward migration from the spawning areas to the latter areas might also involve larvae and juveniles up to a length of $60 \mathrm{~cm}$ or more. After having grown in northern areas for a few years, these fish move south towards mainland Portugal, where they remain a few more years before migrating further south to the spawning areas. This migratory behaviour is expected to be driven by feeding and reproduction (Zilanov and Shepel 1975; Anon. 2000; Figueiredo et al. 2003).

The depth and route of these migratory movements, as well as the contribution of active swimming vs. passive drifting, are unknown. It may be that the species migration makes use of poorly known oceanic features, allowing small juvenile black scabbardfish to reach northern areas. Furthermore, the geographical limitation of the known spawning areas for a species that is widespread in the NE Atlantic suggests the occurrence of particular hydrological or trophic features in those areas. The proposed innovative approach can thus yield new knowledge on the biological as well as physicochemical features of the NE Atlantic deep-sea ecosystem.

In conclusion, several methods have already been used to clarify the migration of this species. So far, otolith shape (Farias et al. 2009), oocyte maturity (Ribeiro Santos et al. 2013a), and microchemical analysis of the larval portion of otoliths (Longmore 2011) support the migratory hypothesis, showing evidence of a single black scabbardfish stock in the NE Atlantic.

Notwithstanding, other techniques have a good potential to provide complementary information. For example, elemental composition of the otolith core could be used to assess whether black scabbardfish from different areas were all born in similar hydrological conditions, i.e., in the same location. Moreover, the combination of fatty acids and stable isotopes provides important information for understanding the structure of this species in the NE Atlantic by elucidating the connection of trophic and reproductive processes with prevailing environmental features in the different areas where the species spends parts of its life cycle.

Acknowledgements. The authors would like to thank Elena Guijarro Garcia (IEO, Spain), Klara Jakobsdóttir (MRI, Iceland), Lise Helen Ofstad (Havstovan, Faroe Islands), Miguel Machete (DOP, Azores), and Sara Reis (DSIP, Madeira) for providing data, and Teresa Moura (IPMA) for helping with the map. This work was supported by the DCF - European Commission Fisheries Data Collection Framework, the EU project Management and monitoring of deep-sea fisheries and stocks (DEEPFISHMAN, Grant No. 227390), the Portuguese project Certificação MSC em Portugal: obtenção de conhecimento e estudos de viabilidade para candidaturas de pescarias costeiras e artesanais (CERTIFICA, PROMAR, 2011-2015), and a doctoral fellowship granted to I. Farias by Fundação para a Ciência e Tecnologia (SFRH/BD/64434/2009). They also thank two anonymous referees for their comments and suggestions.

\section{References}

Allain V., Biseau A., Kergoat B., 2003, Preliminary estimates of French deepwater fishery discards in the Northeast Atlantic Ocean. Fish. Res. 60, 185-192.

Anonymous, 2000, Final report of the EU study project CT 97/0084 - Environment and biology of deep-water species Aphanopus carbo in the NE Atlantic: basis for its management (BASBLACK). DGXIV European Commission.

Anonymous, 2012, $2^{\circ}$ Plano de ajustamento de esforço de pesca: Peixe-espada preto. Direcção de Serviços de Desenvolvimento e Administração das Pescas, Direcção Regional das Pescas, Madeira (in Portuguese).

Biscoito M., Delgado J., Gonzaléz J.A., Sefanni S., Tuset V.M., Isidro E., García-Mederos A., Carvalho D., 2011, Morphological identification of two sympatric species of Trichiuridae, Aphanopus carbo and A. intermedius, in NE Atlantic. Cybium 35, 19-32. 
Bordalo-Machado P., Fernandes A.C., Figueiredo I., Moura O., Reis S., Pestana G., Gordo L.S., 2009, The black scabbardfish (Aphanopus carbo Lowe, 1839) fisheries from the Portuguese mainland and Madeira Island. Sci. Mar. 73, S2, 63-76.

Borets L.A., 1986, Ichthyofauna of the Emperor Seamount Chain and Hawaiian Submarine Ridge. Vopr. Ichtiol 26, 208-220 (in Russian).

Chouvelon T., Spitz J., Caurant F., Mèndez-Fernandez P., Chappuis A., Laugier F., Le Goff E., Bustamante P., 2012, Revisiting the use of $\delta^{15} \mathrm{~N}$ in meso-scale studies of marine food webs by considering spatio-temporal variations in stable isotopic signatures The case of an open ecosystem: The Bay of Biscay (North-East Atlantic). Prog. Oceanogr. 101, 92-105.

Clarke T.A., Wagner P.J., 1976, Vertical distribution and other aspects of the ecology of certain mesopelagic fishes taken near Hawaii. Fish. Bull. 74, 635-645.

Costa V., Lourenço M.H., Figueiredo I., Carvalho L., Lopes H., Farias I., Pires L., Afonso C., Vieira A.R., Nunes M.L., Gordo L.S., 2009, Mercury, cadmium and lead in black scabbardfish (Aphanopus carbo Lowe, 1839) from mainland Portugal, the Azores and Madeira archipelagos. Sci. Mar. 73S2, 77-88.

Crabtree R.E., Sulak K.J., 1986, A contribution to the life history and distribution of Atlantic species of the deep-sea fish genus Conocara (Alepocephalidae). Deep-Sea Res. Part I, 33, 1183-1201.

Dalsgaard J., St. John M., Kattner G., Müller-Navarra D., Hagen W., 2003, Fatty acid trophic markers in the pelagic marine environment. Adv. Mar. Biol. 46, 225-340.

Delgado J., Reis S., González J.A., Isidro E., Biscoito M., Freitas M., Tuset V.M., 2013, Reproduction and growth of Aphanopus carbo and A. intermedius (Teleostei: Trichiuridae) in the northeastern Atlantic. J. Appl. Ichthyol. 29, doi: 10.1111/jai.12230.

Du Buit M.-H., 1978, Alimentation de quelques poissons téléostéens de profondeur dans la zone du seuil de Wyville Thomson. Oceanol. Acta 1, 129-134 (in French).

Ehrich S., 1983, On the occurrence of some fish species at the slopes of the Rockall Trough. Arch. Fisch. 33, 105-150.

Farias I., Vieira A.R., Gordo L.S., Figueiredo I., 2009, Otolith shape analysis as a tool for stock discrimination of the black scabbardfish, Aphanopus carbo Lowe, 1839 (Pisces: Trichiuridae), in Portuguese waters. Sci. Mar. 73S2, 47-53.

Figueiredo I., Bordalo-Machado P., Reis S., Sena-Carvalho D., Blasdale T., Newton A., Gordo L.S., 2003, Observations on the reproductive cycle of the black scabbardfish (Aphanopus carbo Lowe, 1839) in the NE Atlantic. ICES J. Mar. Sci. 60, 774-779.

Fitch J.E., Gotshall D.W., 1972, First record of the black scabbardfish, Aphanopus carbo, from the Pacific Ocean with notes on other Californian trichiurid fishes. Bull. South. Calif. Acad. Sci. 71, 12-18.

Freitas I.C.L., 1998, Contribuição para o conhecimento da ecologia alimentar do peixe-espada preto, Aphanopus carbo Lowe, 1839 (Pisces: Trichiuridae), no Arquipélago da Madeira. Relatório de Estágio do Curso de Biologia, Universidade da Madeira, Funchal (in Portuguese).

Gorbunova N.N., 1977, Larvae of some trichiuroid fishes (Pisces, Trichiuroidae: Gempylidae, Trichiuridae. Trudy IOAN SSSR 109, 133-148 (in Russian).

Gordo L.S., Sena-Carvalho D., Figueiredo I., Reis S., Machado P.B., Newton A., Gordon J., 2000, Escala de maturação sexual do peixe-espada preto: uma abordagem macro e microscópica. The sexual maturity scale of black scabbardfish: a macro- and microscopic approach. Celta Editora, Oeiras (in Portuguese and English).
Graham M.S., Haedrich R.L., Fletcher G.L., 1985, Hematology of three deep-sea fishes: a reflection of low metabolic rates. Comp. Biochem. Physiol. 80A, 79-84.

Hanel R., Hans-Christian J., Meyer-Klaeden O., Piatkowski U., 2010, Larval fish abundance, composition and distribution at Senghor Seamount (Cape Verde Islands), J. Plankton Res. 32, 1541-1556.

Hilborn R., Walters C.J., 1992, Quantitative Fisheries Stock Assessment: choice, dynamics and uncertainty. Chapman \& Hall, New York.

Howe K.M., Steine D.L., Bond C.E., 1980, First records off Oregon of the pelagic fishes Paralepis atlantica, Gonostoma atlanticum and Aphanopus carbo, with notes on the anatomy of Aphanopus carbo. Fish. Bull. 77, 700-703.

Howell K.L., Heymans J.J., Gordon J.D.M., Duncan J., Ayers M., Jones E.G., 2009, DEEPFISH Project: Applying an ecosystem approach to the sustainable management of deep-water fisheries. Part 1: Development of the Ecopath with Ecosim model. Scottish Association for Marine Science, Oban, UK, Rep. No. 259a.

ICES, 2012, Report of the Working Group on the Biology and Assessment of Deep-Sea Fisheries Resources (WGDEEP). ICES CM 2012/ACOM:17.

Kelly C.J., Connolly P.L., Clarke M.W., 1998, The deep waters fisheries of the Rockall trough; some insights gleaned from Irish survey data. ICES CM 1998/O:40.

Kirsch P.E., Iverson S.J., Bowen W.D., 2000, Effect of a low-fat diet on body composition and blubber fatty acids of captive juvenile harp seals (Phoca groenlandica). Physiol. Biochem. Zool. 73, 45-59.

Knutsen H., Catarino D., Sannæs H., Stefanni S., 2009, Development of eleven microsatellite loci in the deep-sea black scabbardfish (Aphanopus carbo). Conserv. Genet. Resour. 1, 89-92.

Lauth R.R., 1997, The 1995 Pacific West coast upper continental slope trawl survey of groundfish resources off southern Oregon and northern California: Estimates of distribution, abundance, and length composition. US Dep. Commer., NOAA Tech. Memo. NMFS-AFSC-80.

Lika K., Nisbet, R. M., 2000, A Dynamic Energy Budget model based on partitioning of net production. J. Math. Biol. 41, 361-386.

Longmore C., 2011, Spatial segregation, habitat use and life- history of two deep-sea teleosts in the North Atlantic. PhD Thesis, University College Dublin.

Machete M., Morato T., Menezes G., 2011, Experimental fisheries for black scabbardfish (Aphanopus carbo) in the Azores, Northeast Atlantic. ICES J. Mar. Sci. 68, 302-308.

Magnússon J.V., Magnússon J., 1995, The distribution, relative abundance, and the biology of the deep-sea fishes of the Icelandic slope and Reykjanes Ridge. In: Hopper A.G. (Ed.) Deepwater Fisheries on the North Atlantic Oceanic Slope, Kluwer Academic, pp. 161-199.

Martins M.R., Leite A.M., Nunes M.L., 1987, Peixe-espadapreto. Algumas notas acerca da pescaria do peixe-espada-preto. Instituto Nacional de Investigação das Pescas (Publicações avulsas), Lisboa (in Portuguese).

Mauchline J., Gordon J.D.M., 1984, Occurrence and feeding of berycomorphid and percomorphid teleost fish in the Rockall Trough. J. Cons. Int. Explor. Mer. 41, 239-247.

Maul G.E., 1950, A espada preta. Publicação da Liga para a Protecção da Natureza 4, 1-10 (in Portuguese).

McAllister D.E., 1990, A list of the fishes of Canada. Syllogeus No. 64. Nat. Mus. Nat. Sci., Ottawa.

Merrett N.R., Haedrich R.L., 1997, Deep-sea demersal fish and fisheries. Chapman and Hall, London. 
Modesto T., Canário A.V.M., 2003, Morphometric changes and sex steroid levels during the annual reproductive cycle of the Lusitanian toadfish, Halobatrachus didactylus. Gen. Comp. Endocrinol. 131, 220-231.

Morales-Nin B., Canha Â., Casas M., Figueiredo I., Gordo L.S., Gordon J.D.M., Gouveia E., Piñeiro C.G., Reis S., Reis A., Swan S.C., 2002, Intercalibration of age readings of deepwater black scabbardfish, Aphanopus carbo Lowe, 1839. ICES J. Mar. Sci. $59,352-364$.

Morales-Nin B., Sena-Carvalho D., 1996, Age and growth of the black scabbardfish Aphanopus carbo off Madeira. Fish. Res. 25, 239-251.

Nakamura I., 1984, Scombrolabracoidai, Scombroidei. In: Masuda H., Amaoka K., Araga C., Uyeno T. (Eds.) The fishes of the Japanese Archipelago. Tokai University Press, Tokyo, pp. 224-228.

Nakamura I., Parin N.V., 1993, Snake mackerels and cutlassfishes of the world (families Gempylidae and Trichiuridae). FAO Fish. Synop. 125, Vol. 15.

Neves A., Vieira A.R., Farias I., Figueiredo I., Sequeira V., Gordo L.S., 2009, Reproductive strategies in black scabbardfish (Aphanopus carbo Lowe, 1839) from the NE Atlantic. Sci. Mar. 73S2, 19-31.

Nogueira N., Cordeiro N., Aveiro M.J., 2013, Chemical composition, fatty acids profile and cholesterol content of commercialized marine fishes captured in Northeastern Atlantic. J. Fish. Sci.com 7, doi: 10.3153/jfscom.2013029.

Pajuelo J.G., González J.A., Santana J.I., Lorenzo J.M., GarcíaMederos A., Tuset V., 2008, Biological parameters of the bathyal fish black scabbardfish (Aphanopus carbo Lowe, 1839) off the Canary Islands, Central-east Atlantic. Fish. Res. 92, 140-147.

Parin N.V., 1986, Trichiuridae. In: Whitehead P.J.P., Bauchot M.-L., Hureau J.-C., Nielsen J., Tortonese E. (Eds.) Fishes of the northeastern Atlantic and the Mediterranean. UNESCO, Paris, Vol. 2, pp. 976-980.

Parin N.V., 1995, Three new species and new records of cutlass fishes of the genus Aphanopus (Trichiuridae). J. Ichthyol. 35, 128-138.

Parin N.V., Becker V.E., 1972, Materials on taxonomy and distribution of some trichiuroid fishes (Pisces, Trichiuroidae: Scombrolabracidae, Gempylidae, Trichiuridae). Trudy Inst. Okeanol. 93, 110-204 (in Russian).

Peden A., 1974. Rare fishes including fish records of thirteen species from British Columbia. Syesis 7, 47-62

Pequeño G., 1989, Peces de Chile. Lista sistemática revisada y comentada. Rev. Biol. Mar., Valparaiso 24, 1-132 (in Spanish).

Perera C.B., 2008, Distribution and biology of Black scabbarfish (Aphanopus carbo Lowe, 1839) in the Northwest of Africa. Tese de Mestrado em Biologia e Gestão em Recursos Marinhos. Faculdade de Ciências, Lisboa.
Piotrovskiy A.S., 1981, On the distribution of the black scabbard fish Aphanopus carbo (Family Trichiuridae) in the Indian Ocean. J. Ichthyol. 19, 145-146.

Ribeiro Santos A., Minto C., Connolly P., Rogan E., 2013a, Oocyte dynamics and reproductive strategy of Aphanopus carbo in the NE Atlantic - Implications for fisheries management. Fish. Res. $143,161-173$.

Ribeiro Santos A., Trueman C., Connolly P., Rogan E., 2013b, Trophic ecology of black scabbardfish, Aphanopus carbo in the NE Atlantic - Assessment through stomach content and stable isotope analyses. Deep-Sea Res. Part I, 77, 1-10.

Santos M.J., Saraiva A., Cruz C., Eiras J.C., Hermida M., Ventura C., Soares J.P., 2009, Use of parasites as biological tags in stock identification of the black scabbardfish, Aphanopus carbo Lowe, 1839 (Osteichthyes: Trichiuridae) from Portuguese waters. Sci. Mar. 73S2, 55-62.

Stacey N.E., Goetz F.W., 1982, Role of prostaglandins in fish reproduction. Can. J. Fish. Aquat. Sci. 39, 92-98.

Stefanni S., Bettencourt R., Knutsen H., Menezes G., 2009, Rapid polymerase chain reaction-restriction fragment length polymorphism method for discrimination of the two Atlantic cryptic deepsea species of scabbardfish. Mol. Ecol. Resour. 9, 528-530.

Stefanni S., Knutsen H., 2007, Phylogeography and demographic history of the deep-sea fish, Aphanopus carbo (Lowe, 1839), in the NE Atlantic: vicariance followed by secondary contact or speciation? Mol. Phylogen. Evol. 42, 38-46.

Stowasser G., McAllen R., Pierce G.J., Collins M.A., Moffat C.F., Priede I.G., Pond D.W., 2009, Trophic position of deep-sea fish Assessment through fatty acid and stable isotope analyses. DeepSea Res. Part I, 56, 812-826.

Templeman W., Squires H.J., 1963, Three records of the black scabbard fish, Aphanopus carbo Lowe, from the Canadian region of Western Atlantic. J. Fish. Res. Board Can. 20, 273-278.

Tuset V.M., Parisi-Baradad V., Lombarte A., 2013, Application of otolith mass and shape for discriminating scabbardfishes Aphanopus spp. in the north-eastern Atlantic Ocean. J. Fish Biol. 82, 1746-1752.

Tuset V.M., Piretti S., Lombarte A., Gonzalés J.A., 2010, Using sagittal otoliths and eye diameter for ecological characterization of deep-sea fish: Aphanopus carbo and A. intermedius from NE Atlantic waters. Sci. Mar. 74, 807-814.

Vieira A.R., Farias I., Figueiredo I., Neves A., Morales-Nin B., Sequeira V., Martins M.R., Gordo L.S., 2009, Age and growth of black scabbardfish (Aphanopus carbo Lowe, 1839) in the southern NE Atlantic. Sci. Mar. 73S2, 33-46.

Zilanov V.K., Shepel L.I., 1975, Notes on the ecology of the black scabbardfish, Aphanopus carbo, of the North-Atlantic. J. Ichthyol. 15, 661-663. 